\title{
University Spin-offs-From the Perspective of Wealth Creation and Research Funding
}

\author{
LUO Rui \\ Zhoukou Normal University, Zhoukou, China
}

\begin{abstract}
University spin-offs not only create huge wealth for university and promote economic growth, but also fulfill the university's mission better, promote the transfer of university knowledge and technology, and advance the university researchers' scientific and technological research motivition. They can fund for universities' scientific research projects and promote the technology transfer from universities to society, so as to enhance national competitiveness. Meanwhile, university spin-offs can provide employment for the high-tech talents, prevent the loss and waste of talents, generate local taxes and promote economic and social development. Thus, university spin-off companies have become a widespread practice in research universities and become wealth creators and research funders. University spin-offs enable universities to better fulfill their missions on the scientific research, talents cultivation, and social services.
\end{abstract}

Keywords: university spin-offs, wealth, research, perspective

\section{Introduction}

University spin-offs are established by the university academic entrepreneurs for the commercialization of university scientific research and service. University spin-offs are effective tools for the transfer of university technology, which not only create university financial resources directly, improve the visibility of the university, but also provide advanced extra courses and practice activity opportunities to attract the best students and provide the teachers with the chances of commercial knowledge to attract and retain the best creative teachers. University spin-offs can also create jobs for educated people, promote the development of regional economics, and enhance the competitiveness of the country.

\section{University Spin-offs-Wealth Creators}

American universities have developed the function of teaching and scientific research of the traditional ones, making social services the third function of the modern universities. Nowadays, American universities have become the pioneers of university reform and make the commercialization of university knowledge become one of the functions of universities. Universities engage in technology licensing and establish the university spin-offs through the establishment of technology transfer institutions, directly promoting the national technology innovation and rapid dissemination of knowledge, and have achieved great success. Under the influence of

LUO Rui, lecturer, master, The Foreign Languages College, Zhoukou Normal University. 
Massachusetts Institute of Technology and Stanford University, other universities in the world have already begun to set up technology transfer mechanisms and university spin-offs.

The boom of American university spin-offs is mainly due to the creation of legislative guarantee function by American federal legislation and traditional university social services rooted in America. This provides support and encouragement for the university operation mechanism to establish university spin-offs. After the promulgation of Morel in America in 1982, legal means have been adopted to ensure that science and technology created by universities should be transferred into the society effectively to create economic and social benefits. After World War II, a number of laws were issued in America so that universities' scientific researches could serve for the commerce and industry and the needs of the country. Among these laws, Bayh-Dole Act has an important impact on the university spin-offs. The Act mainly deals with the barriers of transferring science and technology of the non-profit organizations and small businesses (less than 500 persons). The Act has changed America federal government's technology transfer policy acted of its own free will, established the procedures and patent policy of the federal technology transfer uniform, authorized the universities and small businesses funded by the federal government to apply for patent for their achievements. After the action of the laws, the production of American universities has been greatly improved. For instance, the patent output rate of $\$ 1,000,000$ in research was increased from 0.03 in 1980 to 0.11 in 1997. The number of university technology transfer offices rose from 25 in 1980 to 200 in 1995 (Shane, 2004, p. 30). Later, the promulgation and implementation of "Economic Recovery Tax Act" relieved the tax of enterprises for their funding on university research. "National Cooperative Research Act" reduced antitrust penalty of the enterprise cooperative research activities, so that pre-competitive research between competing industries had become a way approved by the federal government. Under the protection of federal laws, the establishment of university spin-offs is more normative and orderly, which helps to provide a fair competitive environment for university spin-offs market and to further develop and utilize the technology with wide market prospects.

University spin-offs have created huge fiscal revenue for the universities and promoted economic growth. Dutt Maus sold $\$ 64,000,000$ stock equity of Medarex in 2000 . Stanford University sold its $\$ 355,000,000$ stock equity in Google Corporation in 2005. In 1980s, 70\% high-tech companies in the Boston area came from the Massachusetts Institute of Technology laboratory. If Massachusetts Institute of Technology and its spin-offs had not existed, the No. 128 highway economic belt would not have appeared. Statistics from the Association of University Technology Managers showed that American university spin-offs created \$33,500,000,000 from 1980 to 1999 , which indicated that each university spin-off created $\$ 10,000,000$ economic value on average. In addition to direct economic impacts, there are also great indirect impacts. These spin-offs have created 280,000 jobs, each hiring 83 people on average. What is more, they are major employers of high-tech personnel, which has avoided the loss of talents and contributed $\$ 5,000,000,000$ in tax for the federal government.

By 1992, teachers and students from Stanford University had created 1,000 small-scale university spin-offs and employed 20,000 people. As a result, their income had reached \$2,800,000,000. Among them, 78 large ones had reached $\$ 28,000,000,000$ sales revenue. In 2002, Stanford University held the stocks of 70 companies and earned $\$ 20,000,000$ by selling stocks. It also earned $\$ 450,000,000$ licensing fee by technology transfer. By the end of 2009, University of Utah had established 188 companies, among which 98 companies are still in operation, and totally have a staff of 5,937 people. What is more, 9,830 people are indirectly employed due to the purchase 
and consumption. The employees' salary is $\$ 60,000$ per year on average, which is much higher than $\$ 38,000$ per year, which is the average salary in other states in Utah. In 2009, "Entrepreneurial Impact: The Role of MIT", published by Massachusetts Institute of Technology, pointed out that 25,800 existing companies were established by the alumni of Massachusetts Institute of Technology, which employed 3,300,000 people, created \$2 trillion each year, an equivalent of the world's eleventh largest economy, and brought in \$757,000,000 income for the university (Yumiko, 2009).

In 1957, Professor Kenneth Olsen established the Digital Equipment Corporation based on the knowledge ownership of Lincoln Laboratory in Massachusetts Institute of Technology. By 1990, the company's market value had reached $\$ 14,000,000,000$, which ranked No.2 (IBM was No.1 at that time) in the field of computer companies. Nowadays, in the field of biotechnology, there are famous companies like Genentech, Amgen, Biogen, Chiron, and so on. In the field of information technology industry, there are well-known companies like Google, Cisco, Yahoo, Silicon Graphics Inc., Netscape, Lycos, and so on. The market value of Google Corporation had reached $\$ 225,000,000,000$ up to January 2013 (ZHANG, 2009, p. 255). At present, the top 200 American universities have created 651 university spin-offs, and totally there are 3,657 university spin-offs in operation.

In Canada, small companies engaged in scientific research and experiments can get $20-35 \%$ tax credits. In 2000, there were 700 university spin-offs in Canada, generating $\$ 1,400,000,000$ in annual sales revenue and 11,000 jobs. Saskatchewan University established 78 university spin-offs, among which 53 companies are still in operation, totally reaching the market value of $\$ 6,900,000,000$ and creating 3,652 jobs. $91 \%$ of the companies are located in Saskatchewan, and the largest company employs 850 people. Canadian University has created Connaught Laboratories, Macdonald Dettwiler, and other world-renowned university spin-offs.

From 2005 to 2008 , every year 210 new companies were established in the university laboratories in the UK on average. Tom Hockaday, director of technology transfer office in Oxford University, said that 65 enterprises were created by Oxford University over the past 10 years. In the past 20 years, 26 university spin-offs were established by Newcastle University in the UK, which employed 5,000 staff. Enterprises also promote the development of university's scientific research through contract research or joint research projects. $17 \%$ of the high-tech companies in British Cambridge area are university spin-offs. The market value of Turbogenset Corporation, established by King's College, reached $\$ 1,000,000,000$.

In Japan, teachers were civil servants and were not allowed to participate in private business consulting or establish private enterprises before the corporatization of national universities. A lot of university patents belonged to the government or individuals who had no motivation to commercialize their research, which hampered the transfer of knowledge between university and industry. In order to catch up with the developed countries, like America, Japanese government enacted 1,000 "Academic Start-Ups Plans" in 2001, which required its universities to establish 1,000 university spin-offs in the next three years. The target was achieved in 2004 under the support of the government (Sekimizu \& Ogata, 2009, p. 196). After the corporatization of universities, universities are more active to establish spin-offs.

Continental European countries, such as German, France, Sweden, and Norway, also unceasingly increased funding in universities. By establishing spin-offs, universities have become the engines of economic growth and the tools to encourage innovation. For instance, from 1987 to 1997, 40\% of the high-tech companies in France 
were university spin-offs. In Sweden, the first university spin-off was established in 1992 and currently there are still 25 university spin-offs in operation. In Belgium, Catholic University of Louvain has established 61 university spin-offs. These university spin-offs produced 350,000,000 Euros and employed 2,000 people. Two of them were listed on the NASDAQ (National Association of Securities Dealers Automated Quotation) successfully (Inés, David, \& Reinhilde, 2008, p. 189).

In South America, Brazil promulgated innovation laws. Firstly, the laws required all federal universities to establish technology transfer offices. Secondly, they asked public universities to share infrastructure, physical and human resources with private enterprises. Thirdly, public institutions could provide funding for research and development activities of private enterprises. The investment on technology innovation by the Brazilian government was increased by 25.3 times, from $\$ 600,000,000$ in 2000 to $\$ 15,800,000,000$ in 2009 . University of Fed Rio De Janeiro built 30 university spin-offs from 1994 to 2010 (Thiago \& José, 2011)

In China, research universities represented by Tsinghua University took the lead in the establishment of university spin-offs, responsible for the transfer of university technology and commercialization. For example, Tsinghua University Corporation Limited has become one of the 500 strong enterprises in China, with its sales revenue of about $¥ 20,000,000,000$.

The world famous university spin-offs not only create huge wealth, but also promote the employment, support the construction of national innovation system, and enhance the national competitiveness. They are the precious wealth of the country.

\section{University Spin-offs-Miracle Creators}

Compared with other companies, university spin-offs have higher survival rate, which means they can provide more employment, promote economic growth, and create social wealth. A survey of 3,376 university spin-offs, established from 1980 to 2000 in America, shows that $68 \%$ of them could operate to the year of 2001 . University spin-offs in famous universities have higher survival rate. Of 134 university spin-offs established by Massachusetts Institute of Technology from 1980 to 1996, 80\% could operat to 1997. Among 13 spin-offs established by New York University in 1990, 11 are still in business. In France, only 16\% of all the university spin-offs failed within the first six years. In Sweden, among all the spin-offs established between 1960 and 1993, only 13\% failed. In Holland, among all the spin-offs established between 1984 and 1992, only 16\% failed. In Northern Ireland, the spin-offs of Queen's University established between 1984 and 1995 all operated successfully except one until the year of 1997 (Shane, 2004, pp. 30-31).

University spin-offs have higher success rates mainly due to the following factors. Firstly, university scholars suffer great losses of abandoning academic occupations, so they make sound business plans for their spin-offs. Secondly, university spin-offs have technical advantages, because they possess technological innovation which is under patent protection or in tacit knowledge stage. For instance, from 1980 to 1996 Massachusetts Institute of Technology established 134 spin-offs, among which 24 companies' initial public offerings were 257 times than the average new companies. The ordinary university spin-offs issued shares earlier than the common companies. Research shows over $8 \%$ of American university spin-offs are listed companies. Thirdly, university spin-offs may get the support of university business incubators. For example, in Canada, Saskatchewan University provides $\$ 25,000$ initial start-up fund for each technology development project. 
The high survival rate of university spin-offs encourages university entrepreneurs to keep up high morale, improves the success rate of university entrepreneurship, and proves the great potential of universities' scientific research achievements.

\section{University Spin-offs-Research Funders}

University spin-offs can not only create huge economic benefits, but also promote teaching and scientific research of the university. They can fund for universities' scientific research projects and promote the technology transfer from universities to society, so as to enhance national competitiveness. Though university spin-offs can create great wealth, but creating wealth is not the ultimate goal. University spin-offs are effective tools for the transferring of knowledge and technology created by universities. They enable universities to better fulfill their missions on the teaching, scientific research, and social service.

Mary Sue Coleman, President of Michigan University, holds that many people may feel confused in the fact that universities are more and more interested in technology commercialization, nurturing start-ups, and promoting patent and technology licensing agreements. These activities do not aim to get financial income (Abrams, Grace, \& Ashley, 2009, p. 33). Of course, creating revenue can be an incentive, but they are not for money. The first and most important thing is that technology transfer must serve for our core mission: to share our ideas and innovation for the social welfare. In fact, Michigan University has been adhering to the reinvestment on technology transfer from the university finance. In many universities, scientific research costs are much less than the income gained from technical license and the establishment of spin-offs. Therefore, the creation of financial income is not the main objective. This is a simple way to spread new knowledge to the industry and society, so as to improve the competitive force of the country.

University spin-offs can improve the performance of teachers. They can attract and retain prolific teachers in the fields of science and engineering. In spin-offs, teachers are also able to gain supplemental salary opportunity, which helps to prevent them from hopping into other industries for fat salary. Spin-offs can teach teachers to commercialize their technology, so that they can not only engage in scholarship. Meanwhile, teachers can also enable their students to utilize the commercialization of research and realize the value of putting research into practice. This may provide opportunities for doctors and post-doctors to exploit their talents. Louis P. Berneman holds that, scientists who are engaged in entrepreneurial activities in the field of life sciences can improve their research activities by holding the stocks of university spin-offs. In Canada, researchers with spin-offs have increased their research funds by $57 \%$ than before. University teachers need research funds to conduct scientific research, and universities need to cultivate high-level talents. Take these two aspects into consideration, university spin-offs can both improve teachers' ability of scientific research and facilitate their teaching performance.

\section{Conclusion}

The United States has promoted the formation and development of university spin-offs and created many world famous transnational enterprises. University spin-off has become a main form of university academic entrepreneurship from just a tool of technology transfer in the beginning. It has been a common phenomenon for universities throughout the world. University spin-offs can not only create great wealth for universities, but also 
improve universities' level of education and scientific research. Meanwhile, they can provide employment opportunities for the high-tech talents, so as to avoid the overflow or waste of talents. The establishment of university spin-offs is not only for economic consideration, but in many cases for better fulfilling universities' missions on scientific research, talents cultivation, and social services.

\section{References}

Abrams, I., Grace, L., \& Ashley, J. S. (2009). How are U.S. technology transfer offices tasked and motivated-Is it all about the money? Research Management Review, 1, 1-34.

Inés, M. S., David, P, C., \& Reinhilde, V. (2008). Designing contracts for university spin-offs. Journal of Economics \& Management Strategy, 1, 185-218.

Thiago, R., \& José, M. C. De. M. (2011). Analysis of the relationship between academic spin-offs and their parent organization. Paper presented at Triple Helix IX International Conference "Silicon Valley: Global Model or Unique Anomaly?", Stanford University, California.

Sekimizu, N., \& Ogata, Y. (2009). Intellectual property strategies for university spinoffs in the development of new drugs. Drug Discoveries \& Therapies, 5, 193-199.

Shane, S. (2004). Academic entrepreneurship: University spinoffs and wealth creation. USA: Edward Elgar Publishing limited. Yumiko, H. (2009). WIPO university initiative program. The World Intellectual Property Organization.

ZHANG, J. F. (2009). The performance of university spin offs: Evidence spin-from venture capital data. Journal of Technology Transfer, 34, 255-285. 